\title{
Whole or ground millet grain provided in two supplementation frequencies for grazing beef cattle: nutritional parameters
}

\author{
João Marcos Beltrame Benatti ${ }^{1}$, Eduardo Henrique Bevitori Kling de Moraes ${ }^{2}$, Joanis \\ Tilemahos Zervoudakis ${ }^{3}$, Cláudio Vieira de Araújo ${ }^{2}$, Luciano da Silva Cabral ${ }^{3}$, João Rufino \\ Junior $^{4}$, Daniel Marino Guedes de Carvalho ${ }^{5}$, André Alves de Oliveira ${ }^{1}$
}

\footnotetext{
1 Programa de Pós-Graduação em Ciência Animal, Universidade Federal do Mato Grosso, Cuiabá, MT, Brasil.

2 Instituto de Ciências Agrárias e Ambientais/Zootecnia, Universidade Federal do Mato Grosso, Sinop, MT, Brasil.

${ }^{3}$ Departamento de Produção Animal/Faculdade de Agronomia e Medicina Veterinária, Universidade Federal do Mato Grosso, Cuiabá, MT, Brasil.

${ }^{4}$ Programa de Pós-Graduação em Zootecnia, Universidade Federal da Grande Dourados, Dourados, MS, Brasil.

${ }^{5}$ Programa de Pós-Graduação em Agricultura Tropical, Universidade Federal do Mato Grosso, Cuiabá, MT, Brasil.
}

\begin{abstract}
The objective of this study was to evaluate the processing of millet grain provided at two supplementation frequencies for grazing beef cattle during the dry season on nutritional parameters. Five rumen-cannulated crossbred steers, with 24 to 26 months of age and average body weight of $428.6 \pm 26.06 \mathrm{~kg}$, were assigned to a Latin square design $(5 \times 5)$ in a $2 \times 2+1$ factorial arrangement, as follows: two forms of millet grain (whole grains - or ground; WG - GG), two strategies of concentrate supplementation (daily distribution - 7X; or three times a week - 3X) and a control treatment (mineral mixture - MM). Animals were kept in five paddocks of 0.24 ha each with Marandu grass pastures. Concentrate supplements were supplied at 2.00 and $4.66 \mathrm{~kg} / \mathrm{animal} /$ day for treatments $7 \mathrm{X}$ and $3 \mathrm{X}$, respectively. The concentrate supplementation enhanced the intake of total dry matter (DM) and organic matter (OM) and nutrients compared with mineral supplementation. No differences were found between dry matter intake and forage organic matter intake. The values of digestibility coefficients of DM, OM, ether extract, total carbohydrates and non-fiber carbohydrates were increased by concentrate supplementation. Regarding concentrations of rumen ammonia nitrogen, the interactions among time $\times$ treatment $\times$ day and day $\times$ treatment had effects on the measurements of ruminal $\mathrm{pH}$. Plasma urea nitrogen, urinary urea excretion and urinary urea $\mathrm{N}$ excretion differed only between MM treatment and the others, with no interference of grain physical form and supplementation frequency on those variables. The millet grain processing does not alter forage intake, but improves digestibility. Daily supplementation increases digestibility of dry matter and neutral detergent fiber.
\end{abstract}

Key Words: digestibility, frequency, intake, pasture

\section{Introduction}

Forage production seasonality generated by climate factors limits growth, availability and quality of forage with direct effects on animal performance. Thus, concentrate supplement supply in the critical periods of the year has been suggested as an important alternative for optimizing the use of forage nutrients by improving digestibility of the plant cell wall components.

However, the costs with transportation and daily distribution of supplements for grazing cattle are very expressive. Therefore, the use of techniques like rationalization of supplement distribution in intervals of up to six days (Berchielli et al., 2006) has been an alternative

Received April 30, 2013 and accepted January 30, 2014

Corresponding author: jonizoo@yahoo.com.br

http://dx.doi.org/10.1590/S1516-35982014000500005

Copyright (C) 2014 Sociedade Brasileira de Zootecnia. This is an Open Access article distributed under the terms of the Creative Commons Attribution Non-Commercial License, which permits unrestricted non-commercial use, distribution, and reproduction in any medium, provided the original work is properly cited. for beef cattle producers since cattle kept on low quality forage pastures are able to maintain good performance and to efficiently use dry matter, nitrogen and other nutrients compared with daily supplemented animals. However, little is known about the use of this technique in grazing animals consuming tropical forages and the results may vary (Berchielli et al., 2006).

The effect of millet grain in different physical forms for grazing beef cattle is important as the production of this grass is increasing in Brazil, especially in the Central-West region.

According to Theurer (1986), two of the main factors affecting degradation of starch in the rumen are the source of cereal grain and its processing modes. Cereal grinding for ruminant feeding increases the surface contact area and makes the digestive processes, both fermentative an enzymatic, easier (Bolzan et al., 2007).

Thus, the objective of this study was to evaluate whole or ground millet grain, offered daily or at three times a week in multiple supplements on the nutritional parameters of beef cattle grazing on Marandu grass. 


\section{Material and Methods}

The experiment was carried out during the dry season, from August to October, 2008, in Santo Antônio de Leverger, located at the geographical coordinates $15.8^{\circ}$ south latitude and $56.2^{\circ}$ west longitude of Greenwich, and altitude of $140 \mathrm{~m}$.

Five castrated crossbred steers (Angus $\times$ Nellore), with initial average body weight (BW) of $428.6 \pm 26.06 \mathrm{~kg}$, cannulated in the rumen, were assigned to a $5 \times 5$ Latin Square design arranged in a $2 \times 2+1$ factorial arrangement as follows: two physical forms of millet grain (whole [WG] or ground [GG]), two supplementation frequencies (daily or three times a week) and control treatment (mineral mixture $[\mathrm{MM}])$. The experiment consisted of experimental periods of 15 days each, with 10 days for adaptation of the animals at the beginning of each experimental period.

Animals were placed individually in five 0.24-ha paddocks, formed with Brachiaria brizantha cv. Marandu grass, with covered feeders and drinkers. The method of continuous grazing with fixed stocking rate was adopted.

Supplements were offered at $10.00 \mathrm{~h}$ according to a weekly distribution of $14 \mathrm{~kg}$ of concentrate diet per animal. The treatments were composed of combinations between grain physical form and supplementation frequency, as follows: whole millet grain supplied daily ( $2 \mathrm{~kg}$ /animal/day); ground millet grain offered daily ( $2 \mathrm{~kg} /$ animal/day); whole millet grain offered on Mondays, Wednesdays and Fridays (4.66 kg/animal/supplementation event); ground millet grain offered on Mondays, Wednesdays and Fridays (4.66 kg/ animal/supplementation event); and supplementation with mineral mixture (ad libitum).

Experimental supplements (mineral mixture, $25.0 \mathrm{~g} \mathrm{~kg}^{-1}$; urea:ammonium sulfate (9:1), $30.0 \mathrm{~g} \mathrm{~kg}^{-1}$; high energy cottonseed meal, $395.0 \mathrm{~g} \mathrm{~kg}^{-1}$; millet GG or WG, $550.0 \mathrm{~g} \mathrm{~kg}^{-1}$ ) were formulated to provide intake levels of $0.46 \%$ of the body weight (BW) per day and to supply $660.0 \mathrm{~g} \mathrm{~kg}^{-1}$ and $330.0 \mathrm{~g} \mathrm{~kg}^{-1}$ of the daily requirements of crude protein and total digestible nutrients, respectively, for a castrated steer with $450 \mathrm{~kg}$ BW. The expected daily gain was $0.5 \mathrm{~kg} /$ day, according to recommendations of Valadares Filho et al. (2006), with the total dry matter intake estimated at $2 \%$ of BW.

For millet grain processing, a $3.0 \mathrm{~mm}$-sieve disintegrator was used. After processing, the grain had the aspect of thick corn meal and the presence of whole grains was not observed.

Forage was sampled on the first day of each experimental period by two methods. In the first, forage samples were directly collected by cutting the plants at the ground level in three areas restricted to a $0.5 \times 0.5\left(0.25 \mathrm{~m}^{2}\right)$ metal square, followed by a visual representative estimate of the average condition of each paddock. After collections, each sample was weighed and homogenized.

To evaluate total forage dry matter mass (DM kg/ha), a split-sample was collected, identified and analyzed. After that, another split-sample was used to separate the following forage morphological components: green leaf blade, green pseudostem (stem + sheath), dry leaf blade and dry pseudostem; whenever an inflorescence was observed, it was considered pseudostem.

In method 2, the forage consumed by the animals was sampled by manual grazing simulation (simulated grazing), which provides an acceptable estimate of the diet selected by the animals in a grazing regime (Goes et al., 2003; Moraes et al., 2005). Collections were performed following the method of Johnson (1978), by previously identifying the material that the animal would consume. Collection was performed by only one person to avoid variations in each sample.

The percentage of potentially digestible dry matter (pDDM) offered to the animals was calculated from the samples used to estimate total dry matter mass. This result was obtained by the average of neutral detergent insoluble residue (iNDF) evaluated after in situ incubation of the samples in non-woven fabric (TNT) bags $\left(100 \mathrm{~g} / \mathrm{m}^{2}\right)$ for 240 hours (Casali et al., 2008), according to the equation: $\mathrm{pDDM}=0.98 \times(100-\mathrm{NDF})+(\mathrm{NDF}-\mathrm{iNDF})$; in which: $0.98=$ real digestibility coefficient of the cell content; $\mathrm{iNDF}=$ indigestible neutral detergent fiber (NDF).

Forage offer (FO) was calculated according to the following equation:

$$
F O(\%)=\frac{F M X 100}{B W}
$$

in which: $\mathrm{FO}=$ forage offer $(\%) ; \mathrm{FM}=$ forage mass $(\mathrm{kg} \mathrm{DM} /$ ha/day); BW = average body weight of the animals $(\mathrm{kg})$.

Samples were pre-dried in a forced-ventilation oven at $55^{\circ} \mathrm{C}$ for 72 hours and then ground in a Wiley-type knife mill until reaching a $1.0 \mathrm{~mm}$ particle size for laboratorial analyses. Chemical analyses were performed as described by Silva and Queiroz (2002), except for evaluations of NDF and ADF, which followed methods described by Mertens (2002) and Van Soest and Robertson (1985), respectively.

The amount of total carbohydrates (TC) was calculated according to the methodology described by Sniffen et al. (1992), by the following equation: TC $(\%)=100-(\% \mathrm{CP}$ $+\% \mathrm{EE}+\% \mathrm{ash})$.

Non-fibrous carbohydrates (NFC) were quantified according to the adaptation of Hall (2000) by using the equation $\mathrm{NFC}=100-[(\% \mathrm{CP}-\% \mathrm{CP}$ urea $+\%$ urea $)+$ $\%$ NDFap $+\%$ EE $+\%$ ash] . 
Total digestible nutrients (TDN) estimated from forage and from the supplements were calculated according to the equation suggested by NRC (2001). The observed content of TDN was calculated according to the equation proposed by Weiss (1999).

Fifteen grams of the external marker chromium oxide $\left(\mathrm{Cr}_{2} \mathrm{O}_{3}\right)$ were packed in paper cartridge and infused in each animal through the ruminal cannula. The marker was infused at $11.00 \mathrm{~h}$ from day 3 to day 10 of each experimental period and the feces were collected, directly from the rectum, on days $9,10,11$ and 16 at $00.00 \mathrm{~h}$ and $08.00 \mathrm{~h}$.

The chromium content in the feces was determined by using an atomic absorption spectrophotometer and the fecal excretion was estimated by dividing the amount of the supplied marker and its concentration in the feces. Estimate of voluntary intake was obtained using the internal marker iNDF.

To obtain a relationship between intake and live weight of animals, the average weight of the period was used as control, estimated between the average of the initial and final values of each period.

Spot urine samples were collected at spontaneous excretion or from the blood through coccygeal venipuncture four hours after supplement offer $(2.00 \mathrm{~h})$ on the 12th and 13th days of each period to estimate daily excretions of urine and urea and plasma urea concentrations. After that, $10 \mathrm{~mL}$ of urine were diluted in $40 \mathrm{~mL}$ of $\mathrm{H}_{2} \mathrm{SO}_{4}(0.036 \mathrm{~N})$ and frozen at $-20{ }^{\circ} \mathrm{C}$ for further determination of the contents of creatinine and urea according to Valadares et al. (1999). Blood samples were centrifuged at 2,500 rpm for 15 minutes and the plasma was stored in $2 \mathrm{~mL}$ tubes, identified and frozen for further analyses.

Samples of the rumen fluid were collected immediately before supplementation $(10.00 \mathrm{~h}$ - time $0 \mathrm{~h})$ and four hours after supplement offer $(2.00 \mathrm{~h}-$ time $4 \mathrm{~h})$ on the 14 th and 15 th days of each period to measure $\mathrm{pH}$ and ammonia $\left(\mathrm{N}-\mathrm{NH}_{3}\right)$ concentration. The $\mathrm{pH}$ was measured by using a digital pHmeter. To determine ruminal ammonia, a $50 \mathrm{~mL}$ aliquot was separated and packed in a plastic container with $1.0 \mathrm{~mL}$ of $\mathrm{H}_{2} \mathrm{SO}_{4}(1: 1)$, identified and frozen at $-20{ }^{\circ} \mathrm{C}$ for later laboratorial analyses. Concentrations of $\mathrm{N}-\mathrm{NH}_{3}$ in the rumen fluid were determined by the micro-Kjeldahl system with no acid digestion of the sample by distillation with potassium hydroxide $(\mathrm{KOH}) 2 \mathrm{~N}$.

Urine samples were analyzed for contents of urea (modified diacetyl) and creatinine by using commercial kits (Analisa ${ }^{\circledR}$ ), following technical recommendations of the manufacturer. Daily urinary volume was calculated by the ratio between daily creatinine excretion (CE), using the equation proposed by Chizzotti et al. (2008) as control, and its concentration in the spot samples. Thus, it was assumed that daily urea urinary excretion was the product between its concentration in the spot samples and the volume estimated by the urinary volume.

For statistical analyses regarding intake variables, digestibility coefficient and urea excretion, supplements were compared by sum of squares decomposition related to this source by the orthogonal contrasts: a) mineral supplementation versus concentrate supplementation; b) whole millet grain versus ground grain; c) supplementation three times a week (3X) versus daily (7X); and d) interaction between millet grain physical form and supplementation frequency. The computer software SAS (Statistical Analysis System, version 8.2) was used for all statistical analysis, adopting $\alpha=0.10$.

For $\mathrm{N}-\mathrm{NH}_{3}$ and ruminal $\mathrm{pH}$, the split-plot design was used with the period and day in the main plot, hour in the split-plot and treatment in the split-split-plot, adopting the following model: $\mathrm{y}_{\mathrm{ijkh}}=\mu+\tau_{\mathrm{i}}+\beta_{\mathrm{j}}+(\tau \beta)_{\mathrm{ij}}+\gamma_{\mathrm{k}}+(\beta \gamma)_{\mathrm{jk}}$ $+(\tau \beta \gamma)_{\mathrm{i}(\mathrm{jk})}+\delta_{\mathrm{h}}+(\beta \delta)_{\mathrm{jh}}+(\gamma \delta)_{\mathrm{kh}}+(\beta \gamma \delta)_{\mathrm{jkh}}+\varepsilon_{\mathrm{i}(\mathrm{jkh})}$, in which $\mu=$ overall constant; $\tau_{\mathrm{i}}, \beta_{\mathrm{j}}, \gamma_{\mathrm{k}}$ and $\delta_{\mathrm{h}}=$ effects of period, day, hour and treatment, respectively; $(\tau \beta)_{\mathrm{ij}},(\tau \beta \gamma)_{\mathrm{i}(\mathrm{jk})}$ and $\varepsilon_{\mathrm{i}(\mathrm{jkh})}=$ random error per plot, split-plot and split-split-plot, respectively; $(\beta \delta)_{\mathrm{jh}},(\gamma \delta)_{\mathrm{kh}}$ and $(\beta \gamma \delta)_{\mathrm{jkh}}=$ day $\times$ treatment, hour $\times$ treatment, and day $\times$ hour $\times$ treatment interactions, respectively.

Transformation into the logarithmic scale was applied for $\mathrm{N}-\mathrm{NH}_{3}$ for correction of assumptions of normality and homogeneity of variances.

\section{Results}

The total dry matter (TDM) decreased within the first and last experimental periods while an increase of TDM at the third experimental period was observed due to the proportional increase of pseudostem.

Similarly, a decrease in potentially digestible dry matter (pDDM) was observed due to the gradual accumulation of dry pseudostem throughout the experimental period. Additionally, a greater amount of green herbage mass offered to the animals was observed in the last experimental period as a consequence of the enhancement of pseudostem and green leaf blades compared with the other experimental periods (Figure 1).

With regard to forage offer, an average of $10.81 \mathrm{~kg} / 100 \mathrm{~kg}$ of body weight (BW) was observed, while the offer of leaf blades (green + dry) was $3.12 \mathrm{~kg} / 100 \mathrm{~kg}$ of BW, in relation to a leaf blade:pseudostem ratio of 0.41 .

The values observed for pDDM in each experimental period were $16.89,17.00,16.85,13.23$, and $12.99 \mathrm{t} / \mathrm{ha}$,

R. Bras. Zootec., 43(5):250-258, 2014 
which corresponded to 527.0, 543.0, 522.0, 511.0, and $519.0 \mathrm{~g} \mathrm{~kg}^{-1}$ of TDM, respectively. Moreover, pDDM values of $6.31,6.33,6.23,4.86$ and $4.64 \mathrm{~kg} / 100 \mathrm{~kg}$ of BW were observed for each of the five experimental periods, respectively.

Regarding the chemical composition of the forage, crude protein (CP) concentration was $49.3 \mathrm{~g} \mathrm{~kg}^{-1}$, on a DM basis. Conversely, percentages of NDF, ADF, and lignin were high, with $753.9,436.0$ and $81.0 \mathrm{~g} \mathrm{~kg}^{-1}$ on a DM

Table 1 - Chemical composition of supplements and pasture

\begin{tabular}{lcc}
\hline Item & $\begin{array}{c}\text { Concentrate } \\
\text { supplement }\end{array}$ & Pasture \\
\hline${\text { Dry matter }\left(\mathrm{g} \mathrm{kg}^{-1}\right)}_{\text {Organic matter }^{1}}$ & 912.5 & 613.5 \\
Crude protein $^{1}$ & 952.5 & 925.4 \\
Total digestible nutrients $^{1,2}$ & 270.6 & 49.3 \\
NDFap $^{1}$ & 759.1 & 549.4 \\
Neutral detergent fiber $^{1}$ & 271.9 & 738.0 \\
Acid detergent fiber $^{1}$ & 291.8 & 753.9 \\
Neutral detergent insoluble nitrogen $^{3}$ & 158.0 & 436.0 \\
Acid detergent insoluble nitrogen $^{3}$ & 307.7 & 532.8 \\
Ether extract $^{1}$ & 101.1 & 440.8 \\
Mineral matter $^{1}$ & 65.7 & 17.9 \\
Lignin $^{1}$ & 47.6 & 74.6 \\
Total carbohydrates $^{1}$ & 61.8 & 81.0 \\
Non-fibrous carbohydrates $^{1}$ & 616.2 & 858.2 \\
iNDF $^{1}$ & 480.1 & 143.1 \\
iADF $^{1}$ & 18.9 & 367.7 \\
\hline
\end{tabular}

${ }^{1} \mathrm{~g} \mathrm{~kg}^{-1} \mathrm{DM}$.

${ }^{2}$ NRC (2001).

${ }^{3} \mathrm{~g} \mathrm{~kg}^{-1}$ total $\mathrm{N}$.

NDFap - neutral detergent fiber corrected for ash and protein; iNDF - indigestible neutral detergent fiber; $\mathrm{iADF}$ - indigestible acid detergent fiber. basis, respectively (Table 1). Nonetheless, besides the high values observed for forage fiber fraction, no increase was observed for the intakes of forage dry matter (FDM) and organic matter $(\mathrm{FOM})(\mathrm{P}<0.01)$ for cattle fed concentrate supplement. On the other hand, forage and nutrient intake was not affected $(\mathrm{P}>0.01)$ by supplementation frequency or by the physical aspect of millet grain (Table 2).

With the exception of ether extract $(\mathrm{P}>0.10)$, the coefficients of digestibility of DM and OM as well those of

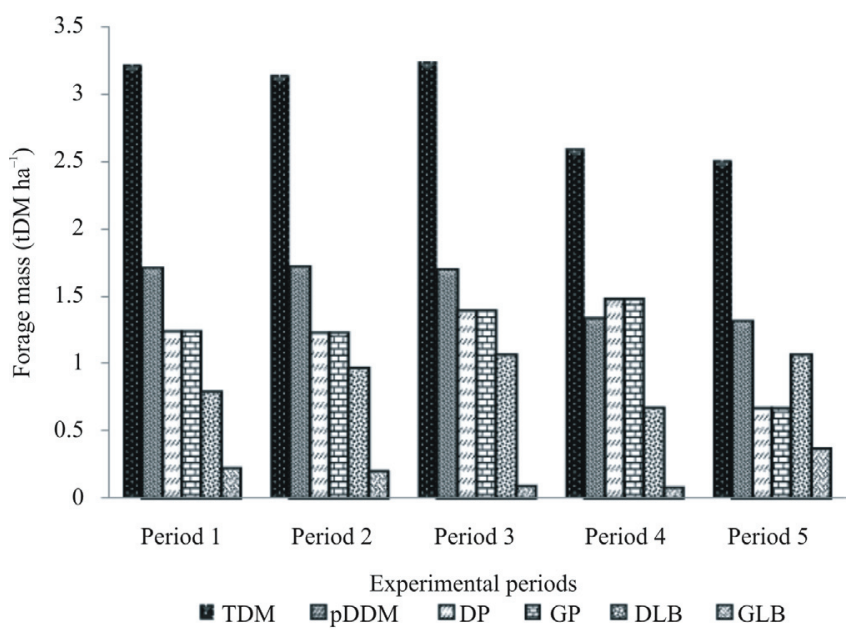

Figure 1 - Total dry matter mass (TDM), potentially digestible dry matter (pDDM), dry pseudostem (DP), green pseudostem (GP), dry leaf blade (DLB) and green leaf blade (GLB) of Marandu Grass in the experimental period.

Table 2 - Nutrient intake by grazing cattle

\begin{tabular}{|c|c|c|c|c|c|c|c|c|c|c|}
\hline \multirow{2}{*}{ Item $^{1}$} & \multirow{2}{*}{$\mathrm{MM}$} & \multicolumn{2}{|c|}{ Whole grain $^{1}$} & \multicolumn{2}{|c|}{ Ground grain ${ }^{2}$} & \multirow{2}{*}{ CV (\%) } & \multicolumn{4}{|c|}{ Contrast } \\
\hline & & $3 X$ & $7 X$ & $3 X$ & $7 X$ & & A & B & $\mathrm{C}$ & D \\
\hline \multicolumn{11}{|c|}{$\mathrm{kg} /$ day } \\
\hline FDM & 5.88 & 6.17 & 6.12 & 6.37 & 6.57 & 11.68 & 0.260 & 0.338 & 0.909 & 0.667 \\
\hline SDM & 0.07 & 1.84 & 1.84 & 1.84 & 1.84 & - & - & - & - & - \\
\hline TDM & 5.95 & 8.02 & 7.94 & 8.21 & 8.42 & 9.43 & $<0.001$ & 0.338 & 0.909 & 0.667 \\
\hline FOM & 5.46 & 5.73 & 5.67 & 5.89 & 6.07 & 11.26 & 0.258 & 0.346 & 0.891 & 0.671 \\
\hline TOM & 5.46 & 7.48 & 7.43 & 7.65 & 7.83 & 9.05 & $<0.001$ & 0.346 & 0.900 & 0.679 \\
\hline $\mathrm{CP}$ & 0.22 & 0.82 & 0.81 & 0.82 & 0.83 & 5.90 & $<0.001$ & 0.434 & 0.695 & 0.699 \\
\hline $\mathrm{EE}$ & 0.15 & 0.28 & 0.30 & 0.29 & 0.29 & 7.50 & $<0.001$ & 0.246 & 0.899 & 0.656 \\
\hline $\mathrm{TC}$ & 5.01 & 6.39 & 6.34 & 6.54 & 6.70 & 9.60 & 0.003 & 0.357 & 0.907 & 0.673 \\
\hline $\mathrm{NDF}$ & 4.41 & 5.07 & 5.02 & 5.25 & 5.30 & 10.57 & 0.015 & 0.349 & 0.889 & 0.871 \\
\hline $\mathrm{NFC}$ & 0.60 & 1.41 & 1.41 & 1.38 & 1.49 & 9.02 & $<0.001$ & 0.589 & 0.971 & 0.162 \\
\hline \multicolumn{11}{|c|}{$\mathrm{kg} / 100 \mathrm{~kg}$ of body weight } \\
\hline FDM & 1.35 & 1.43 & 1.42 & 1.44 & 1.53 & 12.28 & 0.280 & 0.455 & 0.953 & 0.467 \\
\hline TDM & 1.37 & 1.85 & 1.85 & 1.86 & 1.95 & 9.05 & 0.001 & 0.504 & 0.961 & 0.449 \\
\hline FOM & 1.25 & 1.32 & 1.31 & 1.33 & 1.41 & 11.84 & 0.276 & 0.465 & 0.937 & 0.458 \\
\hline TOM & 1.25 & 1.73 & 1.72 & 1.73 & 1.81 & 9.77 & $<0.001$ & 0.518 & 0.954 & 0.446 \\
\hline NDF & 1.02 & 1.17 & 1.16 & 1.19 & 1.23 & 11.10 & 0.019 & 0.489 & 0.921 & 0.613 \\
\hline
\end{tabular}

${ }^{1}$ Whole millet grain supplement.

${ }^{2}$ Ground millet grain supplement.

Item: FDM - forage dry matter; SDM - supplement dry matter; TDM - total dry matter; FOM - forage organic matter; TOM - total organic matter; CP - crude protein; EE - ether extract; TC - total carbohydrates; NDF - neutral detergent fiber; NFC - non-fiber carbohydrates.

MM - mineral mixture.

$3 \mathrm{X}$ - distribution three times a week; $7 \mathrm{X}$ - daily distribution.

Contrasts: A - control treatment versus supplementation; B - whole millet grain versus ground millet grain; C - supplementation three times a week versus daily supplementation; D - interaction between millet grain physical shape and supplementation frequency. 
the other nutrients increased $(\mathrm{P}<0.10)$ with the concentrate supplementation (Table 3).

Ground millet supplementation increased $(\mathrm{P}<0.10)$ the digestibility of DM, OM, EE, TC (total carbohydrates) and NFC (non-fiber carbohydrates). It is noteworthy that a great amount of the whole grain fed to animals was wasted in the feces throughout the experimental period. Thus, a greater digestibility of NFC was observed for animals fed ground millet, which was approximately $18.44 \%$ greater than supplementation with whole grain (Table 3 ).

With regard to frequency of supplementation, no effects were observed $(\mathrm{P}>0.10)$ on digestibility of $\mathrm{OM}, \mathrm{CP}$, EE, TC, and NFC. However, frequency of supplementation affected the digestibility of DM and NDF (Table 3 ).

The observed TDN (obsTDN) increased $(\mathrm{P}<0.10)$ with the inclusion of supplementary resources and grain processing $(\mathrm{P}<0.10)$, leading to a lack of differences
( $\mathrm{P}>0.10)$ among the frequency of supplementation evaluated (Table 3).

No day $\times$ time $\times$ treatment interaction was observed $(\mathrm{P}>0.10)$ for ruminal $\mathrm{N}-\mathrm{NH}_{3}$ concentration. No differences were observed $(\mathrm{P}>0.05)$ among treatments for ruminal $\mathrm{N}_{-} \mathrm{NH}_{3}$ at time 0 (immediately after supplementation) regardless of the day of collection. Difference was observed $(\mathrm{P}<0.10)$ four hours after supplementation when cattle within the group with the lowest frequency of supplementation were not supplemented (day 1), ocurring only for animals supplemented daily (Table 4).

No differences were observed $(\mathrm{P}>0.05)$ for ruminal concentrations of $\mathrm{N}-\mathrm{NH}_{3}$ in the animals fed $\mathrm{MM}$, regardless of time of collection. For animals on the group of the lowest supplementation, difference was observed $(\mathrm{P}<0.01)$ only four hours after supplementation on the day that all animals were supplemented (day 2). On the other hand, for

Table 3 - Mean values $\left(\mathrm{g} \mathrm{kg}^{-1}\right)$ for digestibility coefficient and observed TDN according to the experimental treatments

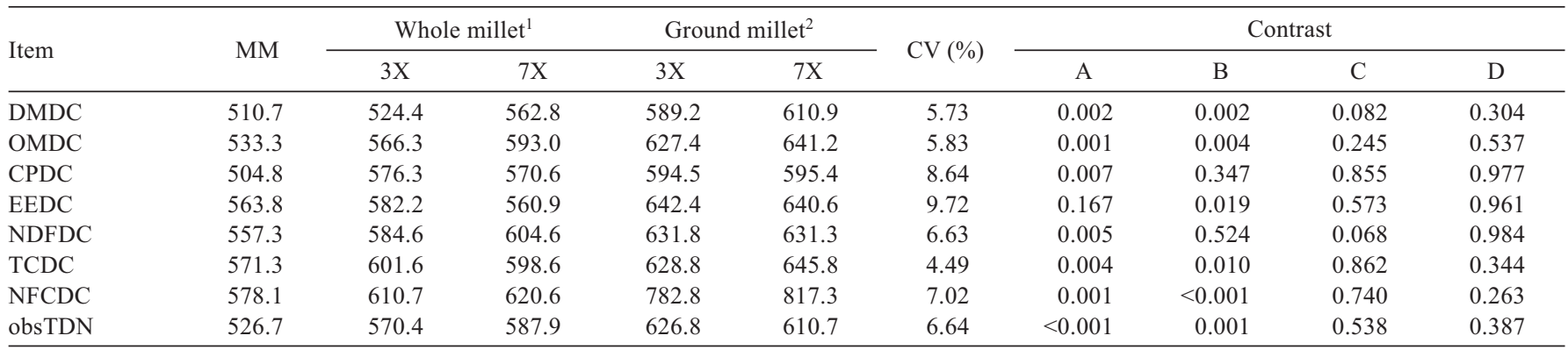

${ }^{1}$ Whole millet grain supplement.

${ }^{2}$ Ground millet grain supplement.

Item: DMDC - dry matter digestibility coefficient; OMDC - organic matter digestibility coefficient; CPDC - crude protein digestibility coefficient; EEDC - ether extract digestibility coefficient; NDFDC - neutral detergent fiber digestibility coefficient; TCDC - total carbohydrates digestibility coefficient; NFCDC - non-fiber carbohydrates digestibility coefficient; obsTDN - observed total digestible nutrients.

MM - mineral mixture.

$3 \mathrm{X}$ - distribution three times a week; $7 \mathrm{X}$ - daily distribution.

Contrasts: A - control treatment versus supplementation; B - whole millet grain versus ground millet grain; C - supplementation three times a week versus daily supplementation;

$\mathrm{D}$ - interaction between millet grain physical shape and supplementation frequency.

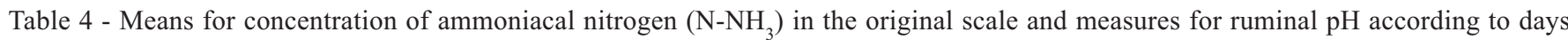
and collection times

\begin{tabular}{|c|c|c|c|c|c|c|}
\hline \multirow{2}{*}{ Day } & \multirow{2}{*}{ Time } & \multirow{2}{*}{ MM } & \multicolumn{2}{|c|}{ Whole millet grain ${ }^{1}$} & \multicolumn{2}{|c|}{ Ground millet grain ${ }^{2}$} \\
\hline & & & $3 X$ & $7 X$ & $3 X$ & $7 X$ \\
\hline & & & & $\mathrm{NH}_{3}(\mathrm{mg} / \mathrm{dL})$ & & \\
\hline \multirow[t]{2}{*}{ Day 1} & 0 & $8.83 \mathrm{Aa}$ & $11.81 \mathrm{Ba}$ & $10.90 \mathrm{Ba}$ & $10.10 \mathrm{Ba}$ & $10.05 \mathrm{Ba}$ \\
\hline & 4 & $9.34 \mathrm{Ab}$ & $12.99 \mathrm{Bb}$ & $27.78 \mathrm{Aa}$ & $10.98 \mathrm{Bb}$ & $25.33 \mathrm{Aa}$ \\
\hline \multirow[t]{3}{*}{ Day 2} & 0 & $9.40 \mathrm{Aa}$ & $10.92 \mathrm{Ba}$ & $10.39 \mathrm{Ba}$ & $10.29 \mathrm{Ba}$ & $10.23 \mathrm{Ba}$ \\
\hline & 4 & $10.74 \mathrm{Ac}$ & $42.48 \mathrm{Aa}$ & $28.56 \mathrm{Ab}$ & $46.31 \mathrm{Aa}$ & $27.12 \mathrm{Ab}$ \\
\hline & & & & $\mathrm{pH}$ & & \\
\hline Day 1 & - & $6.60 \mathrm{~b}$ & $6.38 \mathrm{a}$ & $6.39 \mathrm{a}$ & $6.31 \mathrm{a}$ & $6.48 \mathrm{a}$ \\
\hline Day 2 & - & $6.53 a$ & $6.58 \mathrm{a}$ & $6.41 \mathrm{a}$ & $6.48 \mathrm{a}$ & $6.42 \mathrm{a}$ \\
\hline
\end{tabular}

${ }^{1}$ Whole millet grain supplement

${ }^{2}$ Ground millet grain supplement.

Days: 1 - day when lower supplementation frequency did not receive supplement; 2 - day when all treatments were supplemented

Times: 0 - immediately before supplementation; 4 - 4 hours after supplementation.

MM - mineral mixture.

$3 \mathrm{X}$ - distribution three times a week; $7 \mathrm{X}$ - daily distribution.

Means followed by different uppercase and lowercase letters in the columns and rows, respectively, indicate differences among day levels in each treatment level. 
Table 5 - Plasma urea nitrogen (PUN, mg dL $\left.{ }^{-1}\right)$, urine urea excretion (UE, $\mathrm{g} \mathrm{day}^{-1}$ ) and urine urea nitrogen excretion (UUN, g day ${ }^{-1}$; $\mathrm{UNUE}^{-}$ $\mathrm{mg} \mathrm{kg}{ }^{-1}$ body weight) according to the experimental treatments

\begin{tabular}{|c|c|c|c|c|c|c|c|c|c|c|}
\hline \multirow{2}{*}{ Item } & \multirow{2}{*}{$\mathrm{MM}$} & \multicolumn{2}{|c|}{ Whole millet grain ${ }^{1}$} & \multicolumn{2}{|c|}{ Ground millet grain ${ }^{2}$} & \multirow{2}{*}{$\mathrm{CV}(\%)$} & \multicolumn{4}{|c|}{ Contrast } \\
\hline & & $3 X$ & $7 X$ & $3 X$ & $7 X$ & & A & B & $\mathrm{C}$ & $\mathrm{D}$ \\
\hline PUN & 9.18 & 17.94 & 18.03 & 18.27 & 20.36 & 11.29 & 0.001 & 0.669 & 0.967 & 0.574 \\
\hline UE & 35.62 & 87.03 & 114.95 & 91.35 & 95.20 & 11.05 & 0.001 & 0.531 & 0.423 & 0.935 \\
\hline UUN & 9.60 & 40.04 & 52.88 & 42.02 & 45.79 & 13.49 & 0.001 & 0.531 & 0.423 & 0.935 \\
\hline UNUE & 37.71 & 102.19 & 123.52 & 95.82 & 101.34 & 11.01 & 0.001 & 0.700 & 0.672 & 0.903 \\
\hline
\end{tabular}

${ }^{1}$ Whole millet grain supplement.

${ }^{2}$ Ground millet grain supplement.

MM - mineral mixture.

$3 \mathrm{X}$ - distribution three times a week; $7 \mathrm{X}$ - daily distribution.

Contrasts: A - control treatment versus supplementation; B - whole millet grain versus ground millet grain; C - supplementation three times a week versus daily supplementation;

D - interaction between physical shape of millet grain and supplementation frequency.

animals supplemented daily, there was a difference $(\mathrm{P}<0.01)$ among collection times and a lack of variation of ruminal concentrations of $\mathrm{N}-\mathrm{NH}_{3}(\mathrm{P}>0.05)$ among days of collection (Table 4).

There was a day $\times$ treatment interaction $(\mathrm{P}<0.01)$ for ruminal $\mathrm{pH}$ measurements. Difference was observed $(\mathrm{P}<0.01)$ only for control treatment at day 1 compared with the other treatments (Table 4).

With regard to the results obtained for $\mathrm{N}$ concentration in the blood and urine, there was a difference only between mineral mixture and the other treatments for concentrations of plasma urea nitrogen $(\mathrm{P}<0.01)$, urea excretion $(\mathrm{P}<0.01)$, and urea nitrogen excretion $(\mathrm{P}<0.01)$, with no effects of grain processing and supplementation frequency (Table 5).

\section{Discussion}

This study was carried out during the dry season, in which the temperature and precipitation do not allow for adequate plant growth. Additionally, the animal forage intake, senescence of the plant, and degradation of several forage constituents led to a reduction of total pasture dry matter. Moreover, at the end of the experimental period, due to the beginning of the rainy season and consequently appearance of new tillers, there was an increase in green mass offered to the animals. It should be noted that the maximum forage intake occurs when cattle are grazing on pastures with great leaf availability where the forage intake is impaired by the amount of stem and dead matter of the pasture (Euclides, 2001).

Thus, as the structural characteristics of the forage directly affect the intake of grazing animals and consequently their performance, forage utilization may be optimized with increments of potentially digestible dry matter availability (Paulino et al., 2008).

It can be inferred that there was an interaction between forage intake and supplementary resources, since greater pasture dry matter intake was observed in supplemented animals, which allows the use of beneficial effects and/ or minimizes the negative effects of this the pasture $x$ supplementation interaction (Paulino et al., 2008).

Therefore, the minimum amount of potentially digestible dry matter required to associate the production per animal and per area was achieved, as the efficiency of pasture use occurs when the potentially digestible dry matter offer is between 4 and $5 \mathrm{~kg} / 100 \mathrm{~kg}$ of body weight (Paulino et al., 2004).

Conversely, the crude protein level of the pasture was lower than the $70 \mathrm{~g} \mathrm{~kg}^{-1}$ recommended by Van Soest (1994) and Lazzarini et al. (2009) as minimum values for the rumen microbial activity. Thus, nitrogen supplementation in addition to adequate levels of potentially digestible dry matter is recommended during critical periods of the year such as the dry season, resulting in greater use of the forage fiber.

Since an active microbial population is necessary for the digestion of cell wall components (Paulino et al., 2004), the feed intake may be regulated by ruminal repletion due to the high dietary NDF with low degradation rates. In the present study the forage can be classified as lowquality (Moraes et al., 2006), as forage with ADF values of approximately $300 \mathrm{~g} \mathrm{~kg}^{-1}$ or lower results in high animal intake, while those with ADF values of $40 \mathrm{~g} \mathrm{~kg}^{-1}$ result in lower forage intake (Sarmento, 2003). The animal intake results observed in this study corroborate those reported by Schauer et al. (2005). With regard to grain processing and animal intake, according to NRC (2000), the effect of processing can be less evident when the dietary energy availability is high or when the animal intake is low.

Regarding the digestibility among animals receiving diets with or without supplement, the lower digestibility values of the diets of animals receiving only mineral mixture may be related to the lower values of crude protein and greater levels of fiber in low-quality forage (Bohnert et al., 2002), 
because such combination causes an inadequate ruminal environment for substrate utilization and microbial growth. This scenario becomes more evident when the data on ruminal $\mathrm{N}-\mathrm{NH}_{3}$ of supplemented cattle is analyzed, since it was likely increased due to protein supplementation as the level of pasture protein was lower than $70 \mathrm{~g} \mathrm{~kg}^{-1}$, which serves as substrate for cellulolytic bacteria, increasing the microbial growth and thus the digestibility of the diet. Our findings corroborate those reported by Ferrell et al. (2001) and Paula (2008), who observed lower values for crude protein digestibility in diets for animals supplemented with mineral mixture only.

With regard to grain processing, the rate of ruminal digestion of starch is enhanced in ground grain, since it breaks the pericarp down, allowing the access to starch by the microorganisms (McAllister and Cheng, 1996). Therefore, reduction of the particle size increases the availability of soluble nutrients for fermentation and the exposure of internal parts of the grain for microbial colonization, facilitating digestion (Restle, 2009), as observed in the present study. Similarly, Moron et al. (2000), evaluating whole, cracked or ground grain of sorghum and corn, observed a greater starch degradation in ground and cracked grains compared with the whole grain, stating that the reduction of particle size plays an important role on starch degradation.

Additionally, as previously mentioned, we observed a great grain content in the feces of animals fed whole grain, which may have decreased the digestibility of these diets. Indeed, the observed feed intake was in accordance with predicted feed intake, suggesting that the greater digestibility of the diets with ground grain was as expected, since the grain processing was performed aiming to increase the digestion rate and use of the grain in the ruminal environment.

Diet digestibility was not affected by frequency of supplementation. However, the amount of total digestible nutrients observed was increased likely due to the inclusion of more digestible concentrate and to the greater coefficient of digestibility of the diets containing ground grain.

The concentration of $\mathrm{N}-\mathrm{NH}_{3}$ was similar for days and time of collection, within the same day, when cattle were fed only mineral mixture, suggesting that changes in this variable are dependent on the concentration of $\mathrm{N}$ that reaches the ruminal environment. This fact may also be corroborated when variations among collection times within the same day were observed for animals supplemented daily, and changes in $\mathrm{N}-\mathrm{NH}_{3}$ concentration at day 4, for the animals receiving supplement with lower frequency.

Those events occur because ruminant animals have the ability to maintain the $\mathrm{N}$ levels for a long period by changing the permeability of the gastrointestinal tract to urea and/or by the regulation of its renal excretion, thus keeping it available for the ruminal bacteria during the supplementation intervals (Bohnert et al., 2002).

Moreover, the associations between protein supplementation and the increase in $\mathrm{N}^{-\mathrm{NH}_{3}}$ concentration in the ruminal environment should be considered (Del Curto et al., 1990), which might explains the peaks of $\mathrm{N}_{-} \mathrm{NH}_{3}$ when animals received greater amount of supplement (lower supplementation frequency). Additionally, considering that the adequate concentration of $\mathrm{N}^{-\mathrm{NH}_{3}}$ for ruminal fermentation in animals under tropical conditions is $10.0 \mathrm{mg} / \mathrm{dL}$ (Leng, 1990; Lazzarini, 2007), it can be inferred that only control treatment had values lower than these recommendations.

Ruminal $\mathrm{pH}$ remained above the minimum value required for adequate ruminal development $(>6.0)$, thus preventing the reduction of fibrolytic microorganisms, since cellulolytic bacteria are affected by $\mathrm{pH}$ values lower than 6.0. Cellulolytic bacteria are susceptible to severe inhibition at $\mathrm{pH}$ values between 4.5 and 5.0 and their optimum activity is reached at $\mathrm{pH}$ values closer to 6.7 (Van Soest, 1994).

According to Reis et al. (2007), in Brazilian conditions $\mathrm{pH}$ values lower than the ideal values seldom occur, since the level of supplementation is low and the level of fiber intake is high. As such, there animals produce more saliva, which in turn has a great buffer capacity and high concentration of low-degradation structural carbohydrates.

Corroborating these finds, Detmann et al. (2005), in a study with supplementation of $4 \mathrm{~kg}$ of supplement per animal under grazing conditions during the transition of dry to rainy season, observed ruminal $\mathrm{pH}$ values greater than values that impair the growth of fibrolytic bacteria.

The concentration of plasma urea nitrogen remained within the normal values of 6.0 to $27.0 \mathrm{mg} / \mathrm{dL}$ (Pereira et al., 2007).

Bohnert et al. (2002) reported an increase in plasma urea nitrogen as grazing animals fed low-quality forage received protein supplementation. According to Valadares et al. (1997), levels between 13.52 and $15.15 \mathrm{mg} / \mathrm{dL}$ represent values in which maximum microbial efficiency occurs. According to Rennó et al. (2000), part of the urea found in the bloodstream is transferred to the rumen via saliva or through the ruminal epithelium.

As the intake was increased by the concentrate supplementation, greater values of plasma urea nitrogen were observed, followed by a greater urinary excretion of urea. Van Soest (1994) reported that a urinary concentration of urea is positively correlated with the plasma $\mathrm{N}$ concentrations and $\mathrm{N}$ intake.

R. Bras. Zootec., 43(5):250-258, 2014 


\section{Conclusions}

The intake of total dry matter and nutrients are enhanced by energy-protein supplementation without increasing the pasture dry matter intake.

The processing of millet grain increases the digestibility of dry matter and dietary nutrients as well as the daily supplementation elevates the digestibility of dry matter and neutral detergent fiber.

Both frequencies of supplementation (daily or three times per week) and physical aspects (processed or unprocessed) of millet grain provide adequate $\mathrm{pH}$ conditions and ruminal ammonia concentration.

\section{Acknowledgments}

This study was supported by CNPq.

\section{References}

Berchieli, T. T.; Canesin, R. C. and Andrade, C. 2006. Estratégias de suplementação para ruminantes em pastagens. In: Anais da $43^{a}$ Reunião Anual da Sociedade Brasileira de Zootecnia. Sociedade Brasileira de Zootecnia, João Pessoa.

Bohnert, D. W.; Schauer, C. S. and Del Curto, T. 2002. Influence of rumen protein degradability and supplementation frequency on performance and nitrogen use in ruminants consuming lowquality forage: Cow performance and efficiency of nitrogen use in wethers. Journal of Animal Science 80:1629-1637.

Bolzan, I. T.; Sanchez, L. M. B.; Carvalho, P. A.; Velho, J. P.; Lima, L. D.; Morais, J. and Candorin Jr., R. L. 2007. Consumo e digestibilidade em ovinos alimentados com dietas contendo grão de milho moído, inteiro ou tratado com ureia, com três níveis de concentrado. Ciência Rural 37:229-234.

Casali, A. O.; Detmann, E.; Valadares Filho, S. C.; Pereira, J. C.; Henriques, L. T.; Freitas, S. G. and Paulino, M. F. 2008. Influência do tempo de incubação e do tamanho de partículas sobre os teores de compostos indigestíveis em alimentos e fezes bovina obtidos por procedimentos in situ. Revista Brasileira de Zootecnia 37: 335-342.

Chizzotti, M. L.; Valadares Filho, S. C.; Valadares, R. F. D.; Chizzotti, F. H. M and Tedeschi, L. O. 2008. Determination of creatinine excretion and evaluation of spot urine sampling in Holstein cattle. Livestock Science 113:218-225.

Del Curto, T.; Cochran, R. C.; Harmon, D. L.; Beharka, A. A.; Vanzant, E. S. and Johnson, D. E. 1990. Supplementation of dormant tallgrass-prairie forage: I. Influence of varying supplemental protein and (or) energy levels on forage utilization characteristics of beef steers in confinement. Journal of Animal Science 68:515-531.

Detmann, E.; Paulino, M. F.; Valadares Filho, S. C.; Cecon, P. R.; Zervoudakis, J. T.; Cabral, L. S.; Gonçalves, L. C. and Valadares, R. F. D. 2005. Níveis de proteína em suplementos para terminação de bovinos em pastejo durante o período de transição seca/águas: digestibilidade aparente e parâmetros do metabolismo ruminal e dos compostos nitrogenados. Revista Brasileira de Zootecnia 34:1380-1391

Euclides, V. P. B. 2001. Produção intensiva de carne bovina em pasto. p.55-82. In: Anais do Simpósio de Produção de Gado de Corte. SIMCORTE, Viçosa, MG, Brasil.
Ferrel, C. L.; Freetly, H. C. and Goetsch, A. L. 2001. The effect of dietary nitrogen and protein on feed intake, nutrient digestibility, and nitrogen flux across the portal-drained viscera and liver of sheep consuming high-concentrate diets and ad libitum. Journal of Animal Science 79:1322-1328.

Goes, R. H. T. B.; Mancio, A. B.; Lana, R. P.; Valadares Filho, S. C.; Cecon, P. R.; Queiroz, A. C. and Costa, R. M. 2003. Avaliação qualitativa da pastagem de capim tanner-grass (Brachiaria arrecta), por três diferentes métodos de amostragem. Revista Brasileira de Zootecnia 32:64-69.

Hall, M. B. 2000. Neutral detergent-soluble carbohydrates: nutritional relevance and analysis, a laboratory manual. Extension Bulletin, 339. University of Florida, Gainesville.

Lazzarini, I.; Detmann, E.; Sampaio, C. B.; Souza, M. A.; Valadares Filho, F. A. and Oliveira, F. A. 2007. Consumo, pH e concentração de nitrogênio amoniacal ruminal em bovinos alimentados com forragem de baixa qualidade recebendo níveis crescentes de compostos nitrogenados suplementares In: Anais da 44ㄹ Reunião Anual da Sociedade Brasileira de Zootecnia. Sociedade Brasileira de Zootecnia, Jaboticabal.

Lazzarini, I.; Detmann, E.; Sampaio, C. B.; Paulino, M. F.; Valadares Filho, S. C.; Souza, M. A. and Oliveira, F. A. 2009. Dinâmica de trânsito e degradação da fibra em detergente neutro em bovinos alimentados com forragem tropical de baixa qualidade e compostos nitrogenados. Arquivo Brasileiro de Medicina Veterinária e Zootecnia 61:635-647.

Leng, R. A. 1990. Factors affecting the utilization of "poor-quality" forage by ruminants particularly under tropical condition. Nutrition Research Review 3:277-303.

MCallister, T. A. and Cheng, K. J. 1996. Microbial strategies in the ruminal digestion of cereal grains. Animal Feed Science and Technology 62:29-36.

Mertens, D. R. 2002. Gravimetric determination of amylase treated neutral detergent fiber in feeds with refluxing in beakers or crucibles: Collaborative study. Journal of AOAC International 5:1212-1240

Moraes, E. H. B. K.; Paulino, M. F.; Zervoudakis, J. T.; Valadares Filho, S. C. and Moraes, K. A. K. 2005. Avaliação qualitativa da pastagem diferida da Brachiaria decumbens stapf., sob pastejo, no período da seca, por intermédio de três métodos de amostragem. Revista Brasileira de Zootecnia 34:30-35.

Moraes, E. H. B. K.; Paulino, M. F.; Zervoudakis, J. T.; Detmann, E.; Valadares Filho, S. C.; Valadares, R. F. D. and Moraes, K. A. K. 2006. Níveis de proteína em suplementos para novilhos mestiços em pastejo durante o período de transição seca/águas. Revista Brasileira de Zootecnia 35:2135-2143.

Moron, I. R.; Teixeira, J. C.; Oliveira, A. I. G.; David, F. M. and Cassola, M. G. 2000. Cinética da digestão ruminal do amido dos grãos de milho e sorgo submetidos a diferentes formas de processamento. Ciência e Agrotecnologia 24:208-212.

NRC - National Research Council. 2000. Nutrient requeriments of beef cattle. Washington, D.C.

NRC - National Research Council. 2001. Nutrient requirements of dairy cattle. Washington, D.C.

Paula, N. F. 2008. Fontes de proteína em suplementos fornecidos em diferentes frequências para bovinos em pastejo no período seco. Dissertação (M.Sc). Universidade Federal de Mato Grosso, Cuiabá.

Paulino, M. F.; Figueiredo, D. M.; Moraes, E. H. B. K.; Porto, M. O.; Sales, M. F. L.; Acedo, T. S.; Villela, S. D. J. and Valadares Filho, S. C. 2004. Suplementação de bovinos em pastagens: uma visão sistêmica. p.93-139. In: Anais do 4o Simpósio de Produção de Gado de Corte. SIMCORTE, Viçosa, MG, Brasil.

Paulino, M. F.; Detmann, E. and Valadares Filho, S. C. 2008. Bovinocultura funcional nos trópicos. p.275-305. In: Anais do 
6o Simpósio de Produção de Gado de Corte. SIMCORTE, Viçosa, MG, Brasil.

Pereira, K. P.; Véras, A. S. C.; Ferreira, M. A.; Batista, A. M. V.; Marques, K. A. and Fotius, A. C. A. 2007. Balanço de nitrogênio e perdas endógenas em bovinos e bubalinos alimentados com níveis crescentes de concentrado. Acta Animal Science 29:433-440.

Reis, R. A.; Berchielle, T. T.; Oliveira, A. P. and Siqueira, G. R. 2007. Efeito do uso de alto concentrado sobre a saúde e desempenho de animais zebu e cruzados mantidos em pastagens tropicais. p.61-95. In: Anais do 3o Simpósio de Nutrição de Ruminantes, Botucatu.

Rennó, L. N.; Valadares, R. F. D.; Valadares Filho, S. C.; Silva, J. F. C.; Cecon, P. R.; Gonçalves, L. C.; Dias, H. L. C. and Linhares, R. S. 2000. Concentração plasmática de ureia e excreções de ureia e creatinina em novilhos. Revista Brasileira de Zootecnia 29:1235-1243.

Restle, J. 2009. Processamento do grão de aveia para a alimentação de vacas de descarte terminadas em confinamento. Ciência Animal Brasileira 10:496-503.

Sarmento, D. O. L. 2003. Comportamento ingestivo de bovinos em pastos de capim marandu submetidos a regimes de lotação contínua. Dissertação (M.Sc). Escola Superior de Agricultura "Luis de Queiroz"/Universidade de São Paulo, Piracicaba.

Schauer, C. S.; Bohnert, D. W.; Ganskopp, D. C.; Richards, C. J. and Falck, S. J. 2005. Influence of protein supplementation frequency on cows consuming low-quality forage: performance, grazing behaviour, and variation in supplement intake. Journal of Animal Science 83:1715-1725.
Silva, D.J. and Queiroz, A.C. 2002. Análise de alimentos: Métodos químicos e biológicos. Viçosa, Brasil.

Sniffen, C. J.; O'Connor, D. J.; Van Soest, P. J.; Fox, D. G. and Russel, J. B. 1992. A net carbohydrate and protein system for evaluating cattle diets: carbohydrate and protein availability. Journal of Animal Science 70:3562-3577.

Theurer, C. B. 1986. Grain processing effects on starch utilization by ruminants. Journal of Dairy Science 63:1649-1662.

Valadares, R. F. D.; Gonçalves, L. C. Rodrigues, N. M.; Valadares Filho, S. C. and Sampaio, I. B. M. 1997. Níveis de proteína em dietas de bovinos. 4. Concentrações de amônia ruminal e uréia plasmática e excreções de ureia e creatinina. Revista Brasileira de Zootecnia 26:1270-1278.

Valadares, R. F. D.; Broderick, G.; Valadares Filho, S. C. and Clayton, M. K. 1999. Effect of replacing alfafa of silage with high moisture corn on ruminal protein synthesis estimated from excretion of total purine derivatives. Journal of Dairy Science 82:2686-2696.

Valadares Filho, S. C.; Paulino, P. V. R. and Magalhães, K. A. 2006. Exigências nutricionais de zebuínos e tabela de composição de alimentos. Universidade Federal de Viçosa, Viçosa, MG, Brasil.

Van Soest, P. J. 1994. Nutritional ecology of the ruminant. Cornell University, Ithaca.

Van Soest, P. J. and Robertson, J. B. 1985. Analysis of forages and fibrous foods. Cornell University, Ithaca.

Weiss, W. P. 1999. Energy prediction equations for ruminant feeds. p.176-185. In: Cornell Nutrition Conference for Feed Manufacturers. Cornell University, Ithaca. 